IJOLTL, Vol. 3, No. 1, January 2018

p ISSN: 2502 2326; e ISSN: 2502 8278

Http://ijoltl.pusatbahasa.or.id; Email: jjolt1@gmail.com

Center of Language and Culture Studies, Surakarta, Indonesia

Yuhananik. 2018. Using Jigsaw Model to Improve Reading Comprehension of the Ninth Graders of SMPN 1 Karangploso. IJOLTL (2018), 3(1): 51 64.

DOI:10.30957/ijolt1.V3i1.404.

\title{
USING JIGSAW MODEL TO IMPROVE READING COMPREHENSION OF THE NINTH GRADERS OF SMPN 1 KARANGPLOSO
}

\author{
Yuhananik \\ SMPN 1 Karangploso \\ Jl. PB Sudirman 49 Karangploso, Malang \\ Email: yuhananik@gmail.com
}

\begin{abstract}
This study is aimed at improving reading comprehension using jigsaw model of cooperative learning in reading classes. This study used classroom action research as the design. The subject of the study is the nineth graders of SMPN 1 Karangploso Malang. The number of 30 students was assigned as the subject of this study. The subject had low comprehension in reading English texts. The study revealed that the jigsaw model of cooperative learning in teaching reading is effective to increase reading comprehension. Records of the comprehension showed the increase on the first, second, and third test. The average score before jigsaw was given was 6,08. All students took active participation in the last cycle.
\end{abstract}

Keywords: cooperative learning, jigsaw model, reading comprehension.

DOI: $10.30957 /$ ijoltl.v3i1.404.

\section{INTRODUCTION}

This study has two main concerns: to see the implementation of reading techniques made by the students and to see how effective teaching method using jigsaw to increase students achievement in reading comprehension. Reading, as well as other language skills, is placed as one of the important skills for students to be mastered. Here, the teaching of reading is essential for preparing students with the basic reading skill in order to be able to gain information and knowledge from any reading text. Rivers (1981:259) states that reading is the most important activity in any language class, not only as a source of information and a pleasurable activity, but also as a means of consolidating and extending one' $\mathrm{s}$ knowledge of the language.

Reading ability is vital for students to understand scientific texts written in English. With adequate reading proficiency, students are expected to develop their knowledge concerning with a specific context given to them to learn. They are also expected to be able to extract meaning from specific clues in the text, get the gist of it, and obtain specific information from the reading text. 
IJOLTL, Vol. 3, No. 1, January 2018

p ISSN: 2502 2326; e ISSN: 2502 8278

Http://ijoltl.pusatbahasa.or.id; Email: jjolt1@gmail.com

Center of Language and Culture Studies, Surakarta, Indonesia

Yuhananik. 2018. Using Jigsaw Model to Improve Reading Comprehension of the Ninth Graders of SMPN 1 Karangploso. IJOLTL (2018), 3(1): 51 64. DOI:10.30957/ijolt1.V3i1.404.

However, a number of problems are faced by the teacher in the teaching of reading. One of them deals with learning strategy. In teaching reading, the English teachers are demanded to prepare students with a good reading foundation. To this end, teachers need to devise learning and teaching activities that are suitable with students' need and interest. Appropriate strategy which provides interesting activities encourage students to be active and realize the demand that they are supposed to have.

Teachers as the key factor in the learning process should motivate the students to attend actively in reading class. For this reason, the teacher may offer guidance in helping students to engage in the thinking process (Brown, 2001:340). The teacher should also be able to provide a model of teaching or teaching strategy, which can encourage the students to be more active and have strong motivation in reading class. In this case, reading class ideally should be filled with exciting and challenging ideas for discussion. Students can learn by talking, listening, explaining and thinking with others. Students are often able to explain ideas to one another using an informal language, which is readily understood by the peers. In this learning environment, all students have opportunities to take an active part in meaningful ways. Each student has a variety of skills to bring to group work.

This way, the researcher investigates the Jigsaw model of cooperative learning strategy as a model of teaching reading class. It is assumed that this strategy gives more opportunities to solve the EFL classroom's problem on reading comprehension. In addition, this strategy gives benefits to learning process such as in motivating the students, improving social interaction in the classroom, creating a positive learning environment, and improving reading ability.

Jigsaw is developed by Elliot Aronson and his colleagues in 1978 . According to Slavin (1995:122), the jigsaw approach emphasizes a way to help build a classroom as a community of learners where all students are valued. Students work together in small groups in which they must rely on each other. Each group member becomes "specialized" in subject matter and thereby possesses critical information to contribute to classmates. Here, cooperation and mutual trust become valuable and necessary to academic achievement.

The main purpose of Jigsaw is to have each team member become responsible for a specific piece of learning, and then to share that piece with his or her teammates (Stone, 1990:41). Stone (1990) introduces five steps of partnerexpert group Jigsaw. First, each student is assigned a like-topic partner from another team. Second, the partners meet to master the material. Third, the partners' pair becomes expert groups to discuss the material, checking for completeness and agreement. Fourth, the partners meet again to prepare and practice the presentation they will make to their teams. Fifth, the teams meet and the members make their presentation. 
IJOLTL, Vol. 3, No. 1, January 2018

p ISSN: 2502 2326; e ISSN: 2502 8278

Http://ijoltl.pusatbahasa.or.id; Email: jjolt1@gmail.com

Center of Language and Culture Studies, Surakarta, Indonesia

Yuhananik. 2018. Using Jigsaw Model to Improve Reading Comprehension of the Ninth Graders of SMPN 1 Karangploso. IJOLTL (2018), 3(1): 51 64.

DOI:10.30957/ijolt1.V3i1.404.

The research question of this study is stated as follows: "How can cooperative learning strategy with jigsaw model improve students' reading comprehension ability?"

\section{METHODS}

This study uses the design of Collaborative Classroom Action Research (CCAR). The researcher and her collaborator classroom teacher cope with the classroom's problem in teaching reading using Jigsaw model of cooperative learning strategy for some cycles. The researcher applied model by Kemmis and Mc Taggart (1988), which consisted of four steps: (1) planning of action, (2) implementing of action, (3) observing of action, and (4) analysis and reflection. The subject of this study was 30 the ninth graders of SMPN 1 Karangploso Malang.

In the planning step, the researcher prepared an appropriate strategy, designed a lesson plan, provided media, made observation sheets, made field notes, and prepared the criteria of success. The study was considered successful if it met three criteria: (1) students were able to make good improvement in teaching-learning process and achieve the minimum score at 75; (2) students were active in group work discussion, and (3) students were able to enjoy learning reading using the Jigsaw strategy of cooperative learning strategy.

To implement the plan, the researcher carried out the planning in the classroom in two cycles. Cycle 1 was carried out by the researcher with the help of her collaborator who acted as an observer in the learning and teaching activities in Class. The topic discussed in Cycle 1 was about "Social Media and Its Implication." Cycle 2 discussed about "Human Beings as Scientific Resources."

In the observing step, the researcher recorded and collected data about any aspect or event that happened in the teaching and learning process. In this case, the researcher observed what to become the strengths of the Jigsaw model as a strategy in teaching reading. This part functioned as data, data sources, and techniques of data collection.

The researcher used qualitative and quantitative data in presenting the data. To observe the data about the students' improvement in reading comprehension ability, the researcher obtained the data from the students' score both in tests of reading. To gain data about the implementation of the Jigsaw model of Cooperative Learning strategy in teaching reading, and the students' activity in-group work discussion during the class, the researcher observed the class and used observation sheet and field notes.

Data about the students' response toward the process of learning using the Jigsaw model of cooperative learning strategy were obtained from the questionnaire. The data were taken from some sources such as: (1) the result of observation and field notes about the activities of the teaching and learning 
IJOLTL, Vol. 3, No. 1, January 2018

p ISSN: 2502 2326; e ISSN: 2502 8278

Http://ijoltl.pusatbahasa.or.id; Email: jjolt1@gmail.com

Center of Language and Culture Studies, Surakarta, Indonesia

Yuhananik. 2018. Using Jigsaw Model to Improve Reading Comprehension of the Ninth Graders of SMPN 1 Karangploso. IJOLTL (2018), 3(1): 51 64.

DOI:10.30957/ijolt1.V3i1.404.

activities; (2) the result of the student's learning in reading comprehension; (3) the students' final score of reading test in each cycle.

After collecting the data, the next step was reflection. Reflection was the most important part of classroom action research. In the reflecting step, the researcher focused on making a judgment whether a study was successful or not. Here, the researcher compared the result of data analysis with the criteria of success. If all the criteria of success had been fulfilled, the action was stopped but if not, the research was continued to the next cycle by improving and revising the plan.

\section{RESULTS}

\subsection{General Application of the Jigsaw Model in Teaching Reading}

To implement the Jigsaw model of Cooperative Learning strategy, these procedures were applied: grouping students, establishing seat arrangements, designing lesson plan, setting the learning objectives, and designing appropriate media. In the class activity, the teacher followed the process in three stages of activity: pre-reading, whilst reading, and post reading.

In pre-reading activities, the teacher started teaching activity by explaining the specific instructional objectives to direct the students to achieve the aims of the lesson. All the students paid attention to the explanation given. She asked students some questions related to topic discussed. This was aimed at activating the students' background knowledge on the topic discussed. Then, the teacher asked the students to open the reading text in their text book. The assignment was divided into four sections of paragraphs. Each student in the Jigsaw groups had a different section. Finally, the teacher assigned students to set up the expert groups and gave instructions to each group. Each student who got the same section sat in the same expert group.

In whilst reading activity, the teacher assigned the students to read and study the section given. Students had to share ideas and discuss the section with their expert group. While the students were having a discussion, the teacher walked around the class to observe them. After discussing the section, the students were assigned to write notes or a summary that would be presented in their Jigsaw groups. At the end of this stage, the students were assigned to return to their Jigsaw groups.

In post reading activity, each student became a teacher to her Jigsaw group members. In this sense, she should present her section to her group members. The student who had paragraph one, for example, taught the paragraph one to other members, and so on. 20 minutes before the class ended, each student was given a reading test. The test was done in 30 minutes. The passage of the test was the same as the passage in the discussion. It contained 10 reading comprehension questions. At the end of the class, the teacher collected the students' work. 
IJOLTL, Vol. 3, No. 1, January 2018

p ISSN: 2502 2326; e ISSN: 2502 8278

Http://ijoltl.pusatbahasa.or.id; Email: jjolt1@gmail.com

Center of Language and Culture Studies, Surakarta, Indonesia

Yuhananik. 2018. Using Jigsaw Model to Improve Reading Comprehension of the Ninth Graders of SMPN 1 Karangploso. IJOLTL (2018), 3(1): 51 64.

DOI:10.30957/ijolt1.V3i1.404.

\subsection{Findings of Cycle 1}

It was found that the result of improvement in the teaching and learning process and in learning results in Cycle 1 gained little improvement. The average score increased slightly. Only a few students achieved the criteria of success.

Referring to the criteria of success, it was stated that this study was considered successful if it met the criteria of success: the students were able to make good improvement in teaching-learning process and achieve the minimum score at 75 . In fact, the subjects' improvement in the teaching and learning process and in learning results in cycle 1 was surprising. It was found that those subjects gained little improvement, and few students did not achieve the targeted criteria of success. Here, the implementation of the Jigsaw strategy in reading class had not achieved the goal as stated in the criteria of success. In other words, the criteria of the success that were proposed in this study had not been achieved yet in cycle 1 . The researcher and her collaborator made some revisions on the planning of the Jigsaw strategy, which was implemented in cycle 2 by considering several aspects. First, the teacher needed to have more time when she was explaining the material and giving clear instructions that students could catch the teacher's explanation. The teacher had to explain more detail about the material and give wait time for students to ask questions. Second, the teacher needed to manage the time proportionally. Third, the teacher needed to intensify guiding students in every stage of reading, especially for poor reading ability.

\subsection{The Revision of the Plan}

The result of cycle 1 did not achieve the criteria of success. Therefore, there were some revisions that should be made on the lesson plan, such as the learning objectives, time allotment, and classroom management. First, the lesson plan 2 was prepared for one meeting. The instructional materials were prepared well.

Second, in term of giving further explanation about the material, the teacher explained it more detail with more examples. In addition, the teacher also explained the steps to read the passage effectively and gave wait time for students to ask questions.

Third, in term of the time management, the allotted time to complete the assignment was set up proportionally. The time allocation for each stage of reading was managed well so that each stage took the proportional time in accordance with the kind of activities and level of difficulties of each stage. This was aimed at avoiding the teacher spending too much time on certain stage. By doing so, the students used the time more efficiently.

The intensive guidance was given to the students in every stage of reading. When the students were doing the assignment, the teacher proactively guided them without waiting for the students to raise questions. The teacher walked around the class more frequently when students were working together within the 
IJOLTL, Vol. 3, No. 1, January 2018

p ISSN: 2502 2326; e ISSN: 2502 8278

Http://ijoltl.pusatbahasa.or.id; Email: jjolt1@gmail.com

Center of Language and Culture Studies, Surakarta, Indonesia

Yuhananik. 2018. Using Jigsaw Model to Improve Reading Comprehension of the Ninth Graders of SMPN 1 Karangploso. IJOLTL (2018), 3(1): 51 64.

DOI:10.30957/ijolt1.V3i1.404.

expert groups. The aim was to give necessary help and guide the students who needed teacher's helps.

\subsection{Findings of Cycle 2}

Referring to the findings of Cycle 2, the implementation of the Jigsaw model of Cooperative Learning strategy had achieved the criteria of success. Based on the results of the analysis of both teaching and learning process and the subjects' final composition in Cycle 2, it was concluded that the minimum criteria of success prescribed for successful reading comprehension had been achieved. The Jigsaw strategy succeeded in facilitating the students in reading comprehension. The successful of students could be identified from some indicators of success achieved.

First, in the teaching and learning process, all the subjects were able to: (1) find the main ideas of each paragraph; (2) find the explicit information in the passage; (3) find the implicit information in the passage; (4) get the detailed information in the whole passage; (5) make a summary of the section given; and (6) take turns teaching each other what they had learned in their expert groups. In other words, they were able to achieve the criteria prescribed for successful pre reading, whilst reading and post reading. This was indicated by their ability to do the reading test.

Second, dealing with the subjects' reading achievement, all subjects were able to achieve the minimum level (good level) prescribed for successful reading comprehension. In cycle 2 , the average score of the class increased dramatically to 7.70. This was a sharp increase of improvement.

Second, in terms of the implementation of the Jigsaw model, the students as a team could develop social interaction among the group members. They learnt to hear other students, appreciate others' opinion, communicate intensively, and work together to achieve the goal. They shared their ideas, knowledge, and strategies while learning process in the expert groups. They also could improve their academic achievement. Each student interacted socially each other within both in expert groups and Jigsaw groups. The high and low achievers could learn together. They were working together to complete the assignment given. The low achievers improved their reading comprehension ability from the help of the high achievers. This created a positive learning environment in the classroom.

Third, it was also found that students could enjoy learning writing using the Jigsaw strategy. Based on the questionnaire checklists the results showed that 85\% students strongly agreed and agreed that they enjoyed learning English in the classroom through Jigsaw strategy. About $80 \%$ students strongly agreed and agreed that after attending the Jigsaw classroom they could take benefits such as increasing motivation, self esteem, and achievement. Moreover, about $80 \%$ students strongly agreed and agreed that during the Jigsaw classroom, they participated actively within a group, and about $95 \%$ students strongly agreed and 
IJOLTL, Vol. 3, No. 1, January 2018

p ISSN: 2502 2326; e ISSN: 2502 8278

Http://ijoltl.pusatbahasa.or.id; Email: jjolt1@gmail.com

Center of Language and Culture Studies, Surakarta, Indonesia

Yuhananik. 2018. Using Jigsaw Model to Improve Reading Comprehension of the Ninth Graders of SMPN 1 Karangploso. IJOLTL (2018), 3(1): 51 64.

DOI:10.30957/ijolt1.V3i1.404.

agreed that during the Jigsaw classroom, they worked cooperatively with their friends within a group. In addition, about $90 \%$ students helped each other during the learning activity in the classroom.

For above reasons, the researcher and his collaborator thought that it was not necessary to continue this study in the next cycle, because the study was considered successful.

\subsection{Results of Cycles Analysis}

Analysis of the minimum standard of achievement is presented in Table 1 and results of anaysis of each cycle is presented in Table 2 .

Table 1. Mastery learning in each cycle

\begin{tabular}{|l|c|c|}
\hline Action & Test scores & Mastery learning \\
\hline Pre-cycle & $4,5--6,0$ & 16 Students $(47.1 \%)$ \\
\hline Cycle I & $5,5--6,5$ & 24 students $(70.6 \%)$ \\
\hline Cycle II & $7,6--8,0$ & 30 Students $(88.2 \%)$ \\
\hline
\end{tabular}

Table 1 suggests condition of students mastery in three levels: before research is conducted, ongoing process of cycle 1 , and in the cycle 2 . Score before research is between 4.5 and 6.0. Of 34 students, 16 or $47.1 \%$ students achieved the mastery learning 75 . In cycle I, the test score improved slighly that is between 5,5 and 6.5. In this section, 24 or $70.6 \%$ students achieve the mastery learning. This means the research has not been successful and the process should becontinued.

Fortunately, cycle 2 provide students with substantial progress. Of 34 students, 30 or $88.2 \%$ have achieved the mastery learning and the score of test increase between 7,6 to 80 . As the mastery learning has been achieved by $88 \%$ research subject, the research is considered successful and the cycle is ended.

Further analysis is conduced in the students' participatory activities in both cycles. The inventory is based in descriptors the researcher developed for the observation. The identification is based on the cheklist as seen in Table 3 .

Two broad activities to be observed in this study focus upon on task activity and off task activity. On task activity refers to activities students perform when learning process take place. The off task activity indicate activity each student does individually while on process of learning and in group.

Basically, on task activity in cycle 1 has received $71.25 \%$ and increases significantly in cycle 2 that is $92.29 \%$. In addition, the off task activity in cycle is $28.75 \%$ and declines substantially in cycle 2 into $7.71 \%$. Evidently, jigsaw model to teach reading in this research is successful. 
IJOLTL, Vol. 3, No. 1, January 2018

p ISSN: 2502 2326; e ISSN: 2502 8278

Http://ijoltl.pusatbahasa.or.id; Email: jjolt1@gmail.com

Center of Language and Culture Studies, Surakarta, Indonesia

Yuhananik. 2018. Using Jigsaw Model to Improve Reading Comprehension of the Ninth Graders of SMPN 1 Karangploso. IJOLTL (2018), 3(1): 51 64.

DOI:10.30957/ijolt1.V3i1.404.

Table 2. Learning activity in each cycle

\begin{tabular}{|c|c|c|c|}
\hline \multirow{2}{*}{ No. } & \multirow{2}{*}{ Aspects to be observed } & \multicolumn{2}{|c|}{ Action } \\
\hline & & Cycle 1 & Cycle 2 \\
\hline \multirow[t]{5}{*}{1.} & $\begin{array}{l}\text { Activities relevant to learning process (on } \\
\text { task): } \\
\text { 1) implementing group learning } \\
\text { techniques that is effectuve and } \\
\text { efficient }\end{array}$ & $23,47 \%$ & $38,39 \%$ \\
\hline & $\begin{array}{l}\text { 2) working as suggested by } \\
\text { prescription }\end{array}$ & $21,56 \%$ & $29.48 \%$ \\
\hline & 3) team work in group & $15,49 \%$ & $30,51 \%$ \\
\hline & $\begin{array}{l}\text { 4) communicate results of group } \\
\text { activities }\end{array}$ & $10,73 \%$ & $23,39 \%$ \\
\hline & Total & $71,25 \%$ & $92,29 \%$ \\
\hline \multirow[t]{5}{*}{2.} & $\begin{array}{l}\text { Activities that are not relevant to learning } \\
\text { process (off task): } \\
\text { 1) working in his/her own desire }\end{array}$ & $3,35 \%$ & $1,38 \%$ \\
\hline & 2) do not want to work mutually & $12,56 \%$ & $4,21 \%$ \\
\hline & 3) work for other assignment & $7,17 \%$ & $1,56 \%$ \\
\hline & 4) annoying group activities & $5,67 \%$ & $0,56 \%$ \\
\hline & Total & $28,75 \%$ & $771 \%$ \\
\hline
\end{tabular}

\section{DISCUSSION}

This study has been designed to see the implementation of jigsaw model to teach reading comprehension. This study achieves successful implementation as prescribed in the design.

Primarily, the success has been achieved prior to the beginning of the research. Jigsaw model of Cooperative Learning strategy contributes procedures that help the success: grouping students, establishing seat arrangements, designing lesson plan, setting the learning objectives, designing appropriate media, and dividing the time allotment. Evidences that support the success lay on the focus of planning that involves: (1) designing instructional objectives, (2) selecting appropriate material, (3) preparing media, (4) designing instructional procedures, and (5) designing the procedures of assessment. It was identified that the appropriate model of teaching ESP reading through the Jigsaw model of Cooperative Learning strategy required the teacher to do a particular technique in each stage of reading including pre reading, whilst reading and post reading. 
IJOLTL, Vol. 3, No. 1, January 2018

p ISSN: 2502 2326; e ISSN: 2502 8278

Http://ijoltl.pusatbahasa.or.id; Email: jjolt1@gmail.com

Center of Language and Culture Studies, Surakarta, Indonesia

Yuhananik. 2018. Using Jigsaw Model to Improve Reading Comprehension of the Ninth Graders of SMPN 1 Karangploso. IJOLTL (2018), 3(1): 51 64. DOI:10.30957/ijolt1.V3i1.404.

Other evidence that support the success incorporate the division of techniques of teaching reading. Pre-reading activities involved introducing students to a particular text, providing appropriate background knowledge, and activating necessary schemata. Previewing a text should arouse the students' interest and help them be familiar to the text. Before coming to the topic discussed, the teacher asked students related to the topic. It was done in order to activate the students' background knowledge toward the topic discussed. Here, students were asked to answer a number of questions orally. This was done in order to direct the students to the topic, and to build on students' previous experience.

As prescribed, the students were asked to (1) pay attention to the teacher's explanation on the specific instructional objectives; (2) setting up their Jigsaw groups; ( 3) brainstorming anything related to the topic discussed; (4) having the piece of paragraph to be discussed in their expert groups; (5) setting up their expert groups; and (6) paying attention to the teacher's instructions what they should do in their expert groups.

In addition, there were several activities related to the implementation of the Jigsaw strategy in whilst reading stage. First the students defined the unfamiliar words found in the text. This activity was aimed at equipping the students with some words found in the text. Second, the students worked in their expert group. In this sense, each student obtained a piece of paragraph. Each student had to master it and became an expert of it. Here, the teacher assigned the students to read and study the section given. Students had to share ideas and discuss the section with their expert group.

In the expert groups, students worked cooperatively on their section given, completed some comprehension exercises in expert worksheets and made a summary of the text given. This was done for preparing their presentation to their Jigsaw group members. While the students were having a discussion, the teacher walked around the class to observe them and make helpful comments and suggestions.

Third, after having more or less fifteen minute discussion, the students were assigned to write notes or a summary that would be presented in their Jigsaw groups. During this activity, most students seemed to be more active since they had responsibility to teach their Jigsaw groups. At the end of this stage, the students were assigned to return to their Jigsaw groups.

In the post reading stage, the main activity was that the students were working in the Jigsaw groups. When all expert groups had mastered the section given, students returned to their Jigsaw groups. Here, each student became a teacher to his or her Jigsaw group members. In their Jigsaw groups, students took turns teaching each other what they had learned in their expert groups. The student who had responsibility for paragraph 1, had to teach the group about his or 
IJOLTL, Vol. 3, No. 1, January 2018

p ISSN: 2502 2326; e ISSN: 2502 8278

Http://ijoltl.pusatbahasa.or.id; Email: jjolt1@gmail.com

Center of Language and Culture Studies, Surakarta, Indonesia

Yuhananik. 2018. Using Jigsaw Model to Improve Reading Comprehension of the Ninth Graders of SMPN 1 Karangploso. IJOLTL (2018), 3(1): 51 64. DOI:10.30957/ijolt1.V3i1.404.

her findings in the expert group discussion. Then, the representative of paragraph 2 taught his or her findings, and so on until the last paragraph.

Other evidences that the researcher should take into account are associated with the benefits and drawbacks of the study.

The results of the students' reading achievement throughout this study were classified into two types, i.e. process and product. In terms of process, the students' learning achievement was obtained from their involvement in group activities. Meanwhile, in terms of product, the students' reading achievement was obtained from the results of the students' score of the reading test in each cycle.

Based on the results of the observation conducted throughout the cycles of action, it was found that cooperative skills of the students were gradually improved. The cooperative skills such as taking turn, sharing ideas with each other, developing social interaction among the group members, accepting the role, which had assigned, and so on were achieved during the class activity by students.

Moreover, in Jigsaw classroom, students could learn to hear other students, appreciate others' opinion, communicate intensively, and work together to achieve the goal. They could share their ideas, knowledge, and strategies while learning process in- expert groups. Each student could interact socially each other within a Jigsaw group. The high and low achievers could learn together. They were working together to complete the assignment given.

Consequently, the low achievers could improve better in reading ability. This was evidenced from the improvement of the result scores of the class. In the pretest, the average score of the students' reading achievement was 6.08. Five students got 'poor' level. In cycle 1, the average score of the class increased slightly. This was a slight increase of improvement. Only three students did not achieve the criteria of success. Then, in cycle 2, the average score of the class increased dramatically. This was a sharp increase of improvement. all subjects were able to achieve the minimum criteria (good level) prescribed for successful reading comprehension.

In addition, based on the results of the analysis of both teaching and learning process and the subjects' final composition in Cycle 2, it could also be concluded that the minimum criteria of success prescribed for successful reading comprehension could be achieved. The Jigsaw strategy succeeded in facilitating the students in reading comprehension. The successful of students could be identified from some indicators of success achieved.

First, in the teaching and learning process, all the subjects were able to: (1) find the main ideas of each paragraph; (2) find the explicit information in the passage; (3) find the implicit information in the passage; (4) get the detailed information in the whole passage; (5) make a summary of the section given; and (6) take turns teaching each other what they had learned in their expert groups. 
IJOLTL, Vol. 3, No. 1, January 2018

p ISSN: 2502 2326; e ISSN: 2502 8278

Http://ijoltl.pusatbahasa.or.id; Email: jjolt1@gmail.com

Center of Language and Culture Studies, Surakarta, Indonesia

Yuhananik. 2018. Using Jigsaw Model to Improve Reading Comprehension of the Ninth Graders of SMPN 1 Karangploso. IJOLTL (2018), 3(1): 51 64. DOI:10.30957/ijolt1.V3i1.404.

In other words, they were able to achieve the criteria prescribed for successful pre reading, whilst reading and post reading. This was indicated by their ability to do the reading test.

Second, dealing with the subjects' reading achievement, all subjects were able to achieve the minimum level (good level) prescribed for successful reading comprehension. Most of the subjects were able to achieve the minimum criteria (good level) prescribed for successful reading comprehension.

The implementation of the Jigsaw model of Cooperative Learning strategy in teaching ESP reading gives benefits to students in many ways.

First, it could improve their reading ability. Second, there was a positive interdependence for each member of the groups. Each member had the same chance and responsibilities to present their findings to their Jigsaw groups. In addition, students could share ideas with each other in the Jigsaw classroom. They could work together to accomplish shared goals and do the assignment cooperatively rather than competitively and individualistically.

Third, there was an individual accountability. Each member of the Jigsaw groups had individual responsibility to master the section given, make some important notes about the paragraph, and present the findings to his or her Jigsaw group. This improved the students' self esteem. Through the Jigsaw class experience, students fundamentally changed their self esteem.

Fourth, they perceived that they could reach their learning goal if the other students in the group also reach their goals. They perceived that they were linked with each other in a way that one could not succeed unless everyone succeeded. In this sense, the students were able to do real work together in which they promoted each other's success by sharing ideas, helping, supporting, and encouraging each other's efforts to achieve. Students could learn together so that they subsequently could gain greater individual competency.

Fifth, in the Jigsaw class, it gave students opportunity to interact meaningfully with reading material and gave students responsibility for presenting ideas to other members of the Jigsaw group. It also enabled to integrate four aspects of language skills (reading, writing, listening, and speaking). Class discussion provided students the chances to talk and hear each other. It enabled teachers to interact with students and provide opportunities for students to share ideas and develop their ability to communicate each other.

\section{CONCLUSION}

The study is aimed at improving the students' reading comprehension ability using the Jigsaw model of Cooperative Learning strategy. Based on the research findings and discussions of the study, it can be concluded that the Jigsaw model of Cooperative Learning strategy has been successfully used in improving students' writing ability by implementing the following procedures. 
IJOLTL, Vol. 3, No. 1, January 2018

p ISSN: 2502 2326; e ISSN: 2502 8278

Http://ijoltl.pusatbahasa.or.id; Email: jjolt1@gmail.com

Center of Language and Culture Studies, Surakarta, Indonesia

Yuhananik. 2018. Using Jigsaw Model to Improve Reading Comprehension of the Ninth Graders of SMPN 1 Karangploso. IJOLTL (2018), 3(1): 51 64. DOI:10.30957/ijolt1.V3i1.404.

First, the teacher designed the teaching strategy. Second, he designed the lesson plan. This included designing instructional objectives, selecting appropriate material, preparing media, designing instructional procedures, and designing the procedures of assessment. Third, the teacher managed the organization of Jigsaw classroom. This included: grouping students based on the heterogeneous level of proficiency; assigning the students into Jigsaw groups; and arranging the seat of each group and asking the students to sit face- to- face within their Jigsaw group.

Fourth, the teacher directed the students to the topic discussed. This involved: giving some related questions to the topic; giving wait time to the students to respond the teacher's questions; distributing the expert worksheets to the Jigsaw groups; explaining the procedure of the Jigsaw class; assigning the students to set up expert groups; assigning the students in the expert groups to share ideas with their friends in an expert group, complete the assignment given, and make a summary of the text; and assigning each student in the expert groups to master the section given and prepare for the presentation in their Jigsaw groups.

Fifth, the teacher managed the students' activities in their expert groups. Sixth, the teacher directed the students to the Jigsaw group discussion. This included: facilitating each student to return to their Jigsaw groups; explaining the procedure of doing the discussion in the Jigsaw group; assigning each student to present his or her findings in the expert groups to their friends in the Jigsaw group; assigning students to help each other ; managing the time for discussion appropriately; and making comments and suggestions. Seventh, the teacher gives individual reading test.

\section{REFERENCES}

Arronson, Elliot, et. al. 1978. The Jigsaw Classroom. London: Sage Publications. Baker, Joanna \& Heather, Westrup. 2000. The English Language Teacher's Handbook: How to Teach Large Classes with Few Resources. London: Continuum.

Brown, Douglas H. 2001. Teaching by Principles: An Interactive Approach to Language Pedagogy. New York: Addison Wesley Longman, Inc.

Burden, P.R., \& Byrd, D.M. 1999. Methods for Effective Teaching. Needham height: Allyn \& Bacon.

Direktorat Pendidikan Menengah Umum.1999. Penelitian Tindakan (Action Research). Departemen Pendidikan dan Kebudayaan, Jakarta.

Gebhard, Jerry G. 2000. Teaching English as a Foreign or Second Language: A Teacher Self-Development and Methodology Guide. The United States of America: The University of Michigan Press.

Grellet, Francois. 1981. Developing Reading Skills: A Practical Guide to Reading Comprehension Exercises. New York: Cambridge University Press.

Gunning, Thomas G. 1992. Creating Reading Instruction for all Children. Needham Heights: Allyn and Bacon. 
IJOLTL, Vol. 3, No. 1, January 2018

p ISSN: 2502 2326; e ISSN: 2502 8278

Http://ijoltl.pusatbahasa.or.id; Email: jjolt1@gmail.com

Center of Language and Culture Studies, Surakarta, Indonesia

Yuhananik. 2018. Using Jigsaw Model to Improve Reading Comprehension of the Ninth Graders of SMPN 1 Karangploso. IJOLTL (2018), 3(1): 51 64. DOI:10.30957/ijolt1.V3i1.404.

Harmer, J. 2000. How to Teach English: An Introduction to the Practice of English Language Teaching. Edinburgh: Addison Wesley Longman.

Hill, Susan \& Tim Hill. 1993. The Collaborative Classroom: A Guide to Cooperative Learning. Victoria: Eleanor Curtain Publishing.

Jacob, Evelyn.1999. Cooperative Learning in Context: An Educational Innovation in Everyday Classroom. Edina Minnesota: Interaction Book Company.

Johnson, David \& Roger Johnson. 2001. Cooperative Learning, (on line), (http://www.clcrc.com/pages/cl.html) Accessed on January 25, 2006.

Johnson, David \& Roger Johnson. 2001. An Overview of Cooperative Learning, (on line), (http://www.clcrc.com/pages/overviewpaper.html) Accessed on January 25, 2006.

Kagan, Spencer. 1992. Cooperative Learning. San Juan Capistrano, CA: Kagan Cooperative Learning.

Kemmis, S. \& Taggart, R.M. 1988. The Action Research Planner. Victoria: Deakin University Press.

Kessler, Carolyn. (Ed). 1992. Cooperative language Learning: A Teacher's Resource Book. Englewood Cliffs: Prentice Hall, Inc.

Larsen, Diane \& Freeman. 2000. Techniques and Principles in Language Teaching. New York: Oxford University Press.

Moore, et.al. 1991. Activities for Context and Content on Immediate Processing in Reading. Quarterly Journal of Experimental Psychology, 30:609-636.

Mc. Niff, Jean.1995. Action Research: Principles and Practice. New York: Routledge.

Nunan, David. 1992. Research Methods in Language Learning. Cambridge: University Press.

Nuttal, Christine. 1989. Teaching Reading Skills in a Foreign Language: Practical Language Teaching. Oxford: Heinemann International.

Omaggio, Alice C. 1986. Teaching Language in Context: Proficiency-Oriented Instruction. Boston: Heinle and Heinle Publishers, Inc.

O’Malley, J.M. \& Pierce, L.V. 1996. Authentic Assessment for English Language Learners. Massachusetts: Addison-Wesley.

Otto, et.al. 1979. How to Teach Reading. Boston: Addison Wesley Pub.

Parsons, Richard D. at. al. 2001. Educational Psychology: A PractitionerResearcher Model of Teaching. Canada: Wadsworth Thomson Learning.

Sharan, Shlomo.(Ed.). 1999. Handbook of Cooperative Learning Methods. London: Praeger Publishers.

Slavin, Robert.E. 1995. Cooperative Learning: Theory, Research, and Practice. Second Edition. Boston: Allyn and Bacon. 
IJOLTL, Vol. 3, No. 1, January 2018

p ISSN: 2502 2326; e ISSN: 2502 8278

Http://ijolt1.pusatbahasa.or.id; Email: ijolt1@gmail.com

Center of Language and Culture Studies, Surakarta, Indonesia

Yuhananik. 2018. Using Jigsaw Model to Improve Reading Comprehension of the Ninth Graders of SMPN 1 Karangploso. IJOLTL (2018), 3(1): 51 64. DOI:10.30957/ijoltl.V3i1.404.

Stone, Jeanne. M. 1990. Cooperative Learning and Language Arts: A Multi Structural Approach. San Juan Capistrano, CA: Resources for Teachers, Inc.

Wallace, J. 1995. Improving the Reading Skills of Poor Achieving Students. Reading Improvement, 32(2):102-104). 
IJOLTL, Vol. 3, No. 1, January 2018

p ISSN: 2502 2326; e ISSN: 2502 8278

Http://ijolt1.pusatbahasa.or.id; Email: ijolt1@gmail.com

Center of Language and Culture Studies, Surakarta, Indonesia

Yuhananik. 2018. Using Jigsaw Model to Improve Reading Comprehension of the Ninth Graders of SMPN 1 Karangploso. IJOLTL (2018), 3(1): 51 64.

DOI:10.30957/ijolt1.V3i1.404. 